Terra Nova

April 2008, Volume 20 Issue 2 : Pages 150-153

http://dx.doi.org/10.1111/j.1365-3121.2008.00801.x

(c) 2008 Blackwell Publishing, Inc.
Archimer, archive institutionnelle de l'Ifremer http://www.ifremer.fr/docelec/

\title{
Variations of b-values at the western edge of the Ryukyu Subduction Zone, north-east Taiwan
}

\author{
Jing-Yi Lin ${ }^{1,2, *}$, Jean-Claude Sibuet ${ }^{2}$, Shu-Kun Hsu ${ }^{3}$
}

\author{
${ }^{1}$ Collège de France, Chaire de Géodynamique, Europôle de l'Arbois, Bat. Le Trocadéro - Aile \\ Sud, BP 80, 13545 Aix en Provence cedex 4, France \\ 2 Ifremer, Centre de Brest, DRO/GM, B.P. 70, 29280 Plouzané, France \\ ${ }^{3}$ Institute of Geophysics, National Central University, Chung-Li 32001, Taiwan \\ *: Corresponding author : Jing-Yi Lin, Tel: (33) 442507400 Fax: (33) 4425074 01, email address : \\ lin@cdf.u-3mrs.fr
}

\begin{abstract}
:
Using earthquakes relocated in north-east Taiwan, we estimated b-value distribution along a crosssection located near the Ryukyu slab edge, and four b-value anomalous areas are evidenced: (1) a high $b$-value body lying on top of a low $V p$, low $V s$ and high $V p / V s$ sausage-like body was considered as a region of enhanced partial melt or water supply above which seismicity occurs; (2) beneath the Ilan Plain, an anomalous area characterized by b-values slightly higher than 1.1 might give evidence to the magma conduits to the Kueishantao Island; (3) above the Ryukyu Wadati-Benioff zone, at depths ranging from 90 to $110 \mathrm{~km}$, a high b-value anomaly might correspond to the depth where dehydration occurs in the subducting oceanic plate; and (4) a low b-value area located within the Ryukyu slab, at depths ranging from 70 to $90 \mathrm{~km}$, might be linked to the compressive mechanisms shown by focal mechanisms and the bending of the subducting plate.
\end{abstract}

\section{Introduction}

1. In the westernmost part of the Ryukyu subduction zone where the Philippine Sea (PH) plate converges with the Eurasia (EU) plate at about $8 \mathrm{~cm} / \mathrm{yr}$ along the $\mathrm{N} 306^{\circ}$ direction (Yu et al., 1997) (Figure 1), horizontal compression prevails in the upper plate as suggested by earthquake focal mechanisms (Kao et al., 1998). By using the earthquake distribution, the geometry of the western extremity of the Ryukyu slab was roughly defined (Figures 2a and 2b) (Kao et al., 1998; Font et al., 1999; Chou et al., 2006). More recently, the plate border was imaged by tomographic results. A low $\mathrm{Vp}$, low $\mathrm{Vs}$ and high $\mathrm{Vp} / \mathrm{Vs}$ sausage-like body, about $30 \mathrm{~km}$ in diameter was located at depths ranging between 20 and $100 \mathrm{~km}$ on top of the western Ryukyu slab extremity 
(Lin et al., 2004) (north-dipping dashed contour in Figures 2c to 2g). This body might be the result of asthenospheric rising flow around the slab edge and might be associated with partial melting and/or an increase in $\mathrm{H}_{2} \mathrm{O}$ content. The existence of a magmatic pathway rising from the sausage-like body in direction of the andesitic Kueishantao Island (north-rising dashed contour in Figures 2c to 2g) explains why a slab component was found in the geochemical analyses of the andesites (Lin et al., 2004; Shinjo, 1999). In this study, $b$-value distributions will be calculated near the Ryukyu slab border where complex tectonic mechanisms are involved and compared with tomographic results.

2. The Gutenberg-Richter frequency-magnitude relationship $\log N=a-b M$ (Ishimoto and Iida, 1939; Gutenberg and Richter, 1944) gives the number $N$ of events, with a magnitude equal or larger than $M$ (cumulative distribution), $a$ and $b$ being positive, real constants. The parameter ' $b$ ' is the slope of the best fitting line of the observed number $N$ in function of the magnitude $M$ (Figure 2h).

3. The decrease of $b$ is interpreted in terms of stress variations depending on either material heterogeneity (Mogi, 1962), stress increase before a main seismic event (Scholz, 1968; Wyss, 1973) or stress decrease with high thermal gradients (Warren and Latham, 1970). For laboratory experiments (Scholz, 1968) and mine excavation measurements (Urbancic et al., 1992), b-values display an inverse relationship with stress: low $b$-values are linked to higher stress, and high $b$ values are linked to lower stress. High $b$-values have been reported in volcanic areas surrounding magma chambers (Warren and Latham, 1970) and in the area of geothermal systems (Wiemer and Wyss, 1997; Wiemer et al., 1998; Murru et al., 1999). High $b$-value anomalies have been also reported at depths of 90-100 km in the Alaskan and New-Zealand subduction zones (Wiemer and Benoit, 1996) and within the subducted slab beneath northeastern Japan (Wyss et al., 2001), 
reflecting slab dehydration and a subsequent increase in pore pressure and a decrease of the effective stress.

\section{Data and Method}

4. Relocation of the earthquakes recorded by the Central Weather Bureau (CWB) from December 1990 to May 1999 in northern Taiwan has been performed by Lin et al. (2004). 3370 earthquakes located north of $23.5^{\circ} \mathrm{N}$ latitude were relocated with the "SIMUL2000" program (Thurber and Eberhart-Phillips, 1999) (Figure 1).

5. The distribution of earthquakes is not homogeneous in northern Taiwan. Most of the earthquakes are associated with the Ryukyu slab while the shallow seismicity around the Ilan Plain is linked to the backarc opening and the left-lateral motion along the Lishan Fault (Figure 1). We thus decided to apply the $b$-value calculation along a cross-section located near the Ryukyu slab edge (Figures 1 and 2a). Along this cross-section, the earthquake distribution is dense enough to get a reliable $b$-value estimation (Figures 1, 2c to 2e). The "Zmap" software (Wiemer, 2001; Wiemer and Wyss, 1994 and 1997) was used to determine the spatial distribution of $b$. In total, 884 earthquakes located within $15 \mathrm{~km}$ on each side of the cross-section have been selected and projected perpendicularly to the cross-section. Sampling volumes are cylinders around a horizontal axis. A sliding spatial window was used to analyze the $b$-values in function of depth with a $5 \times 5 \mathrm{~km}$ grid. $b$-values were calculated in cylinder-shaped volumes with varying radii in order to sample a constant number of events. A constant number of events in each sample is preferred rather than windows with constant width spacing to ensure that a change in sample size does not affect the results. The final number of events in each cylinder was a compromise 
between the spatial resolution and the smoothing effect of large windows and we used 100 events as in similar studies (Wiemer and Benoit, 1996; Power et al., 1998). The resolution is thus a function of cylinder radii (Figure 2g).

6. The completeness of the earthquake catalogue, i.e. the estimation of the so-called threshold magnitude $M c$ is critical. In general, $M c$ magnitude of a data set is obtained plotting $\log N$ (cumulative number of events versus magnitude) and the straight line that fits the data. Following Habermann (1983), $M c$ is the level at which the data fall below the line (e.g. 3.1 in Figure 2h). Once $M c$ values are computed, $b$-values are calculated at every grid node by using weighted least squares methods (Bender, 1983) (Figure 2h).

\section{Results and Discussion}

7. The resolution of $b$-values is high (radii $<10 \mathrm{~km}$ ) around the top of the subducting slab and within the overlying crust and lithosphere (Figures $2 \mathrm{f}$ and $2 \mathrm{~g}$ ). Only $b$-values calculated from cylinders with a radius less than $30 \mathrm{~km}$ are displayed in Figure 2f. $30 \mathrm{~km}$ was chosen as a maximum value to limit the amount of smoothing between grid nodes and to maintain a uniformity in the cylinder size. In our study, we focused the discussion on the areas where the spatial resolution is smaller than $20 \mathrm{~km}$ (Figures $2 \mathrm{f}$ and $2 \mathrm{~g}$ ) to ensure that the observed $b$-value variation represents the real local tectonic structure.

8. Three areas of high $b$-value are observed: the largest one is located on top of the low $V p$, low $V s$ and high $V p / V s$ sausage-like body at depths ranging from 0 to $40 \mathrm{~km}$ (1 in Figure 2f). If the sausage-like body is linked to melt and/or $\mathrm{H}_{2} \mathrm{O}$ enriched material (Lin et al., 2004), 
earthquakes are rather expected to occur around this body. The high $b$-value feature might be linked to earthquakes produced at the boundary between the sausage-like body and the overlying lithosphere. Within this feature, the highest $b$-values ( 1.5) are observed close to the surface, south of the Ilan Plain. Anomalous heat provided by the rising magma might affect the upper brittle crust and trigger the hydrothermal process near the surface, causing these large $b$-values.

9. In the upper crust (0-10 km) near Kueishantao Island, $b$-values are slightly higher than 1.1 (2 in Figure 2f). They correspond to the region of the feeding channel imaged by tomographic results (north-rising red dashed contours in Figures 2c to 2g). As Kueishantao Island magma supply may rise up from the lower crust to the surface through numerous conduits, the whole region may be characterized by $b$-values higher than 1.0.

10. $b$-values higher than 1.0 are observed between depths of 90 and $110 \mathrm{~km}$, above the Wadati-Benioff zone (3 in Figure 2f). They are 20\% higher than in the adjacent volumes of the wedge. The widely accepted concept that dehydration of subducting oceanic crust at about 100 km providing fluids which migrate in the overlying mantle (Gill, 1981; Arculus, 1994) may be at the origin of the increase of pore pressure and decrease of the effective stress. Such dehydration processes in subduction zones linked to high $b$-values were already reported in Alaska, NewZealand and north Japan (Wiemer and Benoit, 1996; Wyss et al., 2001). We consequently suggest that this high $b$-value region might correspond to the depth where the dehydration process of the subducting oceanic PH plate occurs.

11. Significantly low $b$-values are also found within the subducting slab, at depths ranging from 70 to $90 \mathrm{~km}$ (4 in figure 2f). After earthquakes relocation, Chou et al. (2006) showed that the western extremity of the Ryukyu slab was folded beneath the Ilan Plain at 50-100 km depth, 
as a result of the collision between the EU and PH lithospheres (Figure 2b). Horizontal compressive mechanisms were also determined in this area (Kao et al., 1998). According to several laboratory experiment and field studies, a link between low $b$-values and a rise of ambient stress was proposed (Scholz, 1968; Lahaie and Grasso, 1999; Gibowicz and Lasocki, 2001). We consequently suggest that the low $b$-values observed within the Ryukyu slab might be due to the compressive mechanisms detected in the portion of folding slab located in the area of convergence between the $\mathrm{PH}$ and EU plates. These compressive mechanisms do not exist everywhere in the subducted slab (Kao et al., 1998), and it might be the reason why the low $b$ value distribution pattern is not observed along the entire slab.

\section{Conclusions}

12. $\quad b$-values determined along the cross-section located in the vicinity of the Ryukyu slab edge by using Central Weather Bureau relocated earthquakes located within $15 \mathrm{~km}$ on each side of the cross-section provide new insights in the convergence area of the PH and EU plates: (1) high $b$-values lies on top of the low $V p$, low $V s$ and high $V p / V s$ sausage-like body, a region of increased partial melting or water supply, suggesting that regions surrounding magma chambers are seismogenic; (2) the magma feeding channel rising from the sausage-like body to the Kueishantao Island is also characterized by $b$-values slightly higher than 1.1, suggesting that the magma may rise through numerous conduits; (3) above the Ryukyu Wadati-Benioff zone, at depths ranging from 90 to $110 \mathrm{~km}$, the high $b$-values might correspond to the depth of dehydration of the subducting oceanic crust; and (4) the low $b$-value region located within the 
slab, at depths ranging from 70 to $90 \mathrm{~km}$ might be linked to the existence of compressive mechanisms evidenced by focal mechanisms and the folding of the Ryukyu slab extremity.

\section{Acknowledgments}

We thank the Central Weather Bureau of Taiwan for providing land station data. The Zmap software (Wiemer, 2001) was used for the computation of $b$-values. Some of the figures were drawn by using the GMT software package (Wessel and Smith, 1991). This work is part of an ongoing cooperative project between France and Taiwan encouraged and supported by Ifremer, the Institut Français de Taipei and by the National Science Council, Taiwan. Pertinent suggestions proposed by Wen-Nan Wu are acknowledged.

\section{References}

Arculus, R. J., 1994. Aspects of magma genesis in arcs. Lithos, 33, 189-208.

Bender, B., 1983. Maximum likelihood estimation of $b$-values for magnitude grouped data. Bull. Seism. Soc. Am., 73, 831-851.

Chou, H.-C., Kuo, B.-Y., Hung, S.-H. et al., 2006. The Taiwan-Ryukyu subduction-collision complex: Folding of a viscoelastic slab and the double seismic zone. J. Geophys. Res., 111, B04410, doi:10.1029/2005JB003822.

Font, Y., Lallemand, S. and Angelier, J., 1999. Etude de la transition entre l'orogène actif de Taiwan et la subduction des Ryukyus - Apport de la sismicité. Bull. Soc. Géol. France, 170, 271-283. 
Gibowicz, S. J. and Lasocki, S., 2001. Seismicity induced by mining: Ten years later. Adv. Geophys., 44, 39-181.

Gill, J. B., 1981. Orogenic andesite and plate tectonics Springer-Verlag, New York, 390 pp.

Gutenberg, R. and Richter, C. F., 1944. Frequency of earthquakes in California. Bull. Seism. Soc. Am., 34, 185-188.

Habermann, R. E., 1983. Teleseismic detection in the Aleutin Island arc, J. Geophys. Res., 88, 5056-5064.

Ishimoto, M. and Iida, K., 1939. Observations of earthquakes registered with the microseismograph constructed recently. Bull. Earthq. Res. Inst., Univ. Tokyo, 17, 443-478.

Kao, H., Shen, S.-S. J. and Ma, K.-F., 1998. Transition from oblique subduction to collision: Earthquakes in the southernmost Ryukyu Arc - Taiwan region. J. Geophys. Res., 103, 72117229.

Lahaie, F. and Grasso, J. R., 1999. Loading rate impact on fracturing pattern: Lessons from hydrocarbon recovery, Lacq gas field, France. J. Geophys. Res., 104, 17941-17954.

Lin, J.-Y., Hsu, S.-K. and Sibuet, J.-C., 2004. Melting features along the western Ryukyu slab edge (northeast Taiwan): Tomographic evidence. J. Geophys. Res., 109, B12402, doi:10.1029/2004JB003260.

Mogi, K., 1962. Magnitude-frequency relationship for elastic shocks accompanying fractures of various materials and some related problems in earthquakes. Bull. Earthq. Res. Inst., Univ. Tokyo, 40, 831-883.

Murru, M., Montuori, C., Wyss, M. et al., 1999. The location of magma chambers at Mt. Etna, Italy, mapped by b-values. Geophys. Res. Lett., 26, 2553-2556. 
Power, J. A., Wyss, M. and Latchman, J. L., 1998. Spatial variations in frequency-magnitude distribution of earthquakes at Soufrière Hills volcano, Montserrat, West Indies. Geophys. Res. Lett., 25, 3653-3656.

Scholz, C. H., 1968. The frequency-magnitude relation of microfracturing in rock and its relation to earthquakes. Bull. Seism. Soc. Am., 58, 399-415.

Sibuet, J.-C., Deffontaines, B., Hsu, S.-K. et al., 1998. The southwestern Okinawa Trough backarc basin: Tectonics and volcanism. J. Geophys. Res., 103, 30,245-30,267.

Sibuet, J.-C. and Hsu, S.-K., 2004. How was Taiwan created? Tectonophysics, 379, 159-181.

Shinjo, R., 1999. Geochemistry of high Mg andesites and the tectonic evolution of the Okinawa Trough-Ryukyu arc system, Chem. Geol., 157, 69-88.

Thurber, C. H. and Eberhart-Phillips, D., 1999. Local earthquake tomography with flexible gridding. Comput. Geosci., 25, 809-818.

Urbancic, T. I., Trifu, C. I., Long, J. M. et al., 1992. Space-time correlations of $b$-values with stress release. PAGEOPH, 139, 449-462.

Warren, N. W. and Latham, G. V., 1970. An experimental study of thermally induced microfracturing and its relation to volcanic seismicity. J. Geophys. Res., 75, 4455-4464.

Wessel, P. and Smith, W. M. F., 1991. Free software helps map and display data. EOS, Trans., Am. Geophys. Union, 72, 441-446.

Wiemer, S. and Wyss, M., 1994. Seismic quiescence before the Landers (M=7.5) and Big Bear (M=6.5) 1992 earthquakes. Bull. Seism. Soc. Am., 84, 900-916. 
Wiemer, S., 2001. A software package to analyze seismicity: ZMAP. Seismol. Res. Lett., 72, 373382.

Wiemer, S. and Benoit, J. P., 1996. Mapping the b-value anomaly at $100 \mathrm{~km}$ depth in the Alaska and New Zealand subduction zones. Geophys. Res. Lett., 23, 1557-1560.

Wiemer, S., McNutt, S. R. and Wyss, M., 1998. Temporal and three-dimensional spatial analysis of the frequency-magnitude distribution near Long Valley caldera, California. Geophys. J. Int., 134, 409-421.

Wiemer, S. and Wyss, M., 1997. Mapping the frequency-magnitude distribution in asperities: An improved technique to calculate recurrence times? J. Geophys. Res., 102, 15,115-15,128.

Wyss, M., 1973. Towards a physical understanding of the earthquake frequency distribution. Geophys. J. R. Astr. Soc., 31, 341-359.

Wyss, M., Hasegawa A. and Nakajima, J., 2001. Source and path of magma for volcanoes in the subduction of northeastern Japan. Geophys. Res. Lett., 28, 1819-1822.

Yu, S.-B., Chen, H. Y. and Kuo, L.-C., 1997. Velocity field of GPS stations in the Taiwan area. Tectonophysics, 274, 41-59.

\section{Figure Captions}

Figure 1. Hypocenters of 3370 NE Taiwan earthquakes located by the Central Weather Bureau and relocated with the SIMUL2000 program (Thurber and Eberhart-Phillips, 1999) from December 1990 to May 1999. 884 relocated earthquakes in the gray rectangle were used for the computation of spatial $b$-values and projected along the cross-section (Profile 1 ). 
Gray tones show depth ranges. Dashed lines are the isobaths of the Wadati-Benioff zone (Font et al., 1999). Bathymetric contours every 500 m (Sibuet et al., 1998; Sibuet and Hsu, 2004). Simplified map of the Ryukyu subduction zone with slab isobaths every $50 \mathrm{~km}$ (Sibuet et al., 1998) in the inset. The volcanic front (dashed gray line) is located 80-100 $\mathrm{km}$ above the slab. The arrow indicates the Philippine Sea plate motion relative to the Eurasia plate (Yu et al., 1997).

Figure 2. (a) Geographical distribution of low $V p$, low $V s$ and $V p / V s$ values higher than 1.78 (Lin et al., 2004). The areas of high Vp/Vs anomalies are located above the western edge of the Ryukyu slab. The black line shows the position of Profile 1; (b) Geometry of the western extremity of the Ryukyu slab (Chou et al., 2006). Solid and dotted lines show the trace of the trench. The "folding" feature of the slab near the western boundary is evident in comparison with the trace of the trench. The slab bends reversely with respect to the general trend of the Ryukyu trench (dotted lines). Tomographic images and $b$-value distributions for the cross-section 1 are displayed in (c) to (g). (c), (d) and (e): $V p / V s, P$ wave and S-wave velocity perturbations. Stars: earthquakes used in this study; (f) $b$-value distribution. Areas where the resolution is larger than $30 \mathrm{~km}$ are masked. Numbers show the features where $b$-value anomalies are discussed; solid contours show the spatial resolution of 10- and 20- km; (g) Spatial resolution map along the cross-section 1. The north-dipping high $V p / V s$ sausage-like body and the north-rising Kueishantao feeding channel are underlined by dashed lines. (h) Frequency magnitude distribution (FMD) for the two sampled circles located in (f). $b$-values are the slopes of straight best fitting lines estimated from the weighted least squares methods. Mc: magnitude of completeness. 


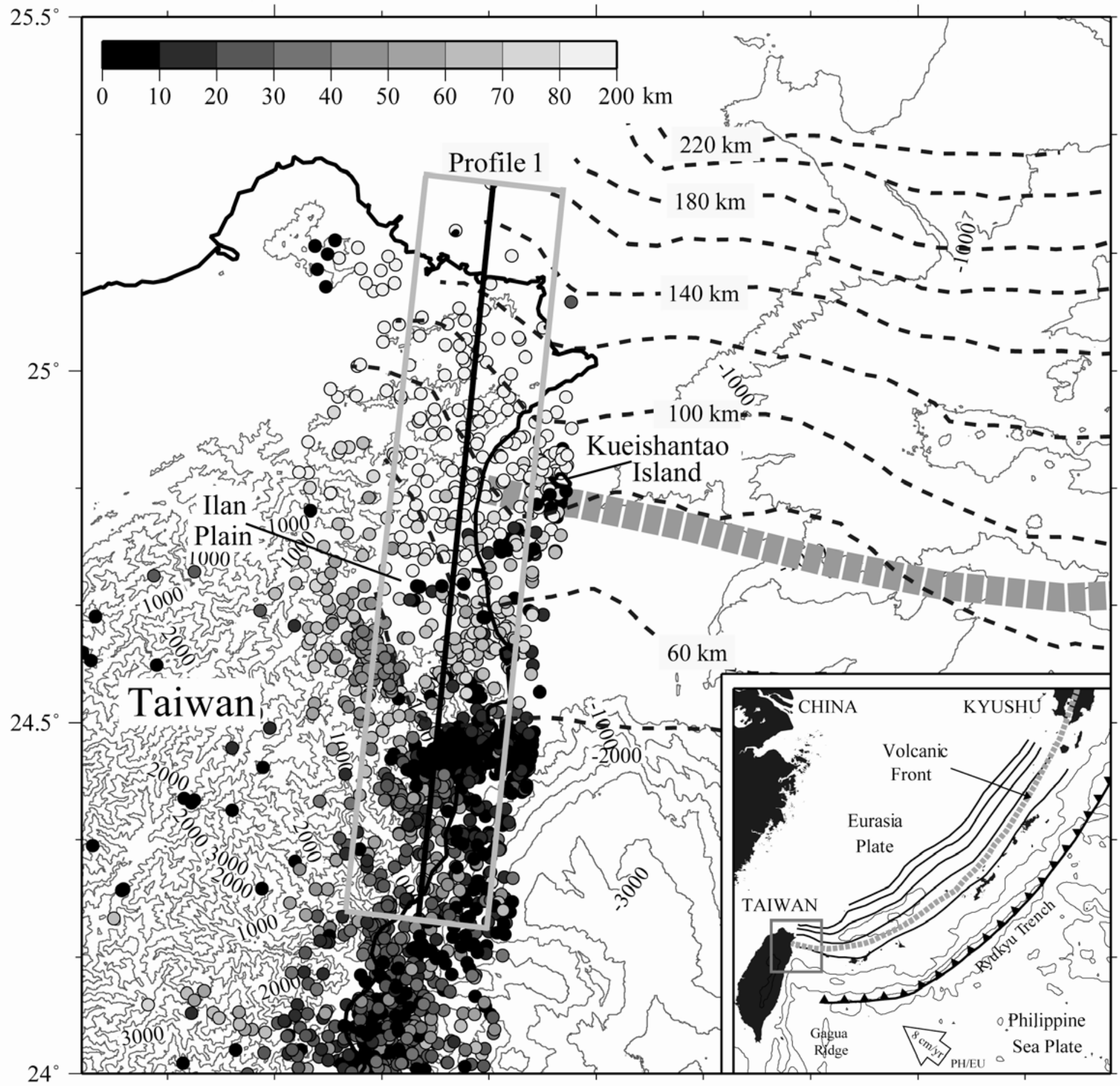

Lin, Sibuet and Hsu, Figure 1 


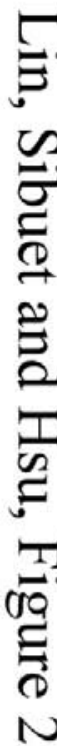
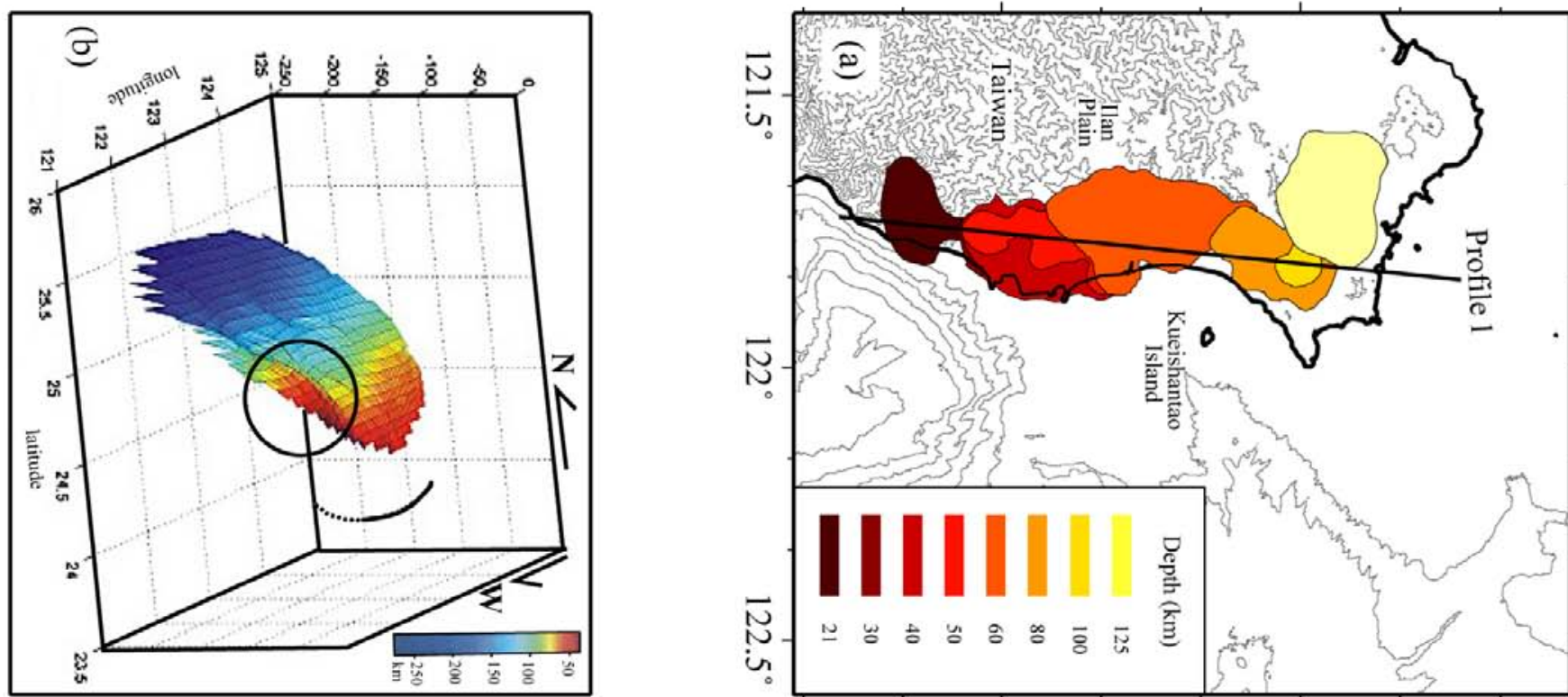

Depth $(\mathrm{km})$
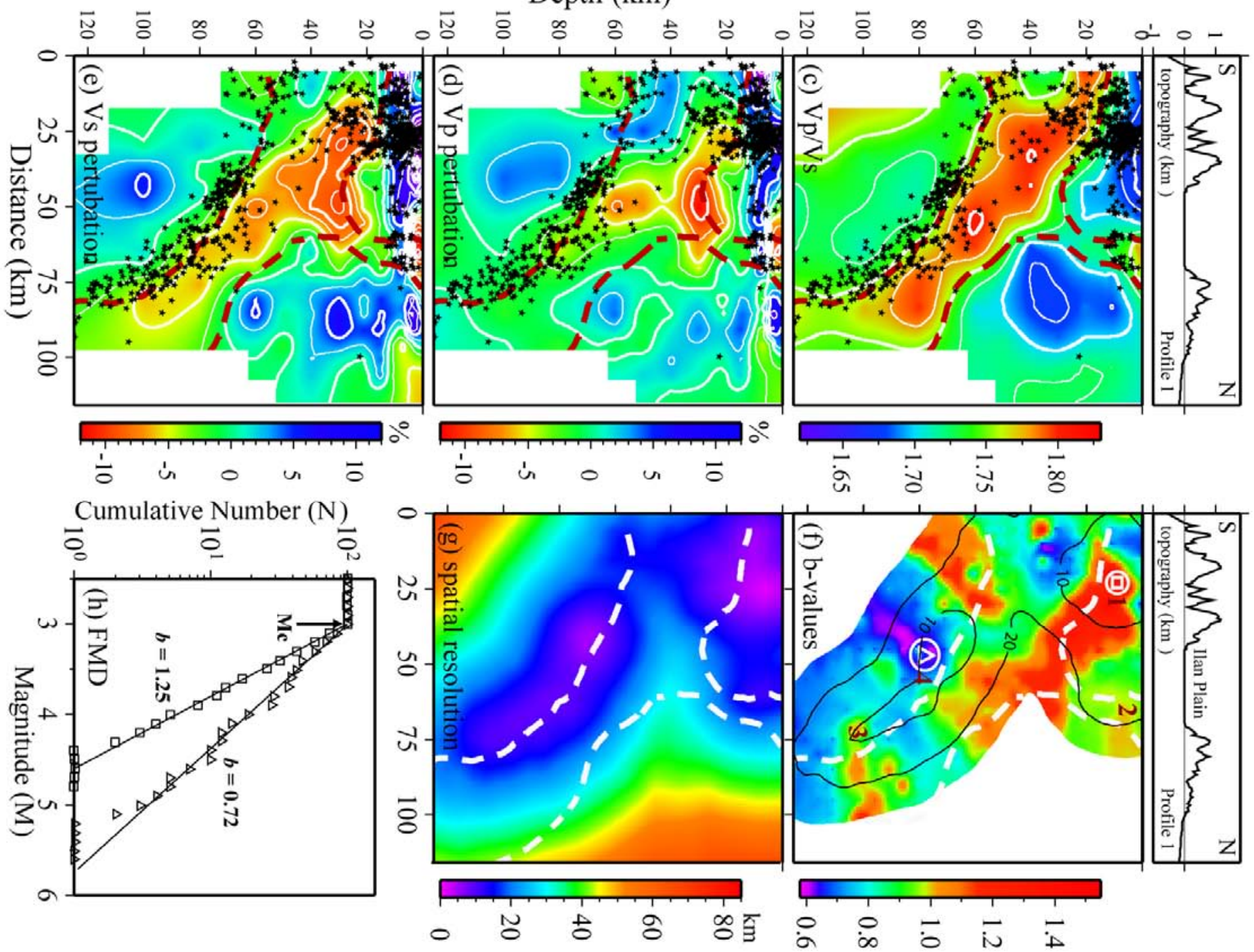